\title{
PENENTUAN NILAI SPF EKSTRAK DAN LOSIO TABIR SURYA EKSTRAK ETANOL DAUN KERSEN (Muntingia calabura L.) DENGAN METODE SPEKTROFOTOMETRI UV-VIS
}

\author{
Erni Widyawati ${ }^{1}$, Nurista Dida Ayuningtyas ${ }^{2}$, Agustina Putri Pitarisa $^{3}$ \\ 1,2,3 Akademi Farmasi Nusaputera Semarang \\ Email Korespondensi : erniwidyawati76@gmail.com
}

\begin{abstract}
ABSTRAK
Paparan sinar matahari yang berlebihan dan berlangsung lama dapat menyebabkan eritema dan kulit terbakar, penuaan dini dan kanker kulit. Daun kersen mempunyai kandungan flavonoid dan fenolik total yang tinggi sehingga dapat dimanfaatkan sebagai bahan aktif pembuatan losio tabir surya. Penelitian ini bertujuan untuk menentukan nilai SPF, nilai Transmisi eritema (\%Te) dan nilai Transmisi pigmentasi (\% Tp) dari ekstrak dan losio ekstrak etanol daun kersen menggunakan metode spektrofotometri Uv-Vis. Absorbansi diukur pada panjang gelombang 290-400 nm dengan interval $5 \mathrm{~nm}$. Hasil penelitian menunjukkan nilai SPF ekstrak dengan konsentrasi 500 ppm, 1000 ppm, dan 2000 ppm berturut- turut adalah 12,15 (kemampuan maksimal) ; 17,29 (proteksi ultra); dan 22,01 (proteksi ultra). Nilai \%Te 0,54; 0,16 dan 0,05 semuanya termasuk kategori total block, nilai \%Tp 2,50; 1,30 dan 0,49 (total block). Sedangkan untuk losio dengan konsentrasi $0,5 \%, 1 \%$ dan $2 \%$ berturut-turut nilai SPF yang dihasilkan yaitu 3,61(proteksi minimal); 8,18 (proteksi maksimal) dan 10,13 (proteksi maksimal). Nilai $\%$ Te 4,29 (ekstra proteksi); 1,58 (ekstra proteksi) dan 0,99 (proteksi maksimal). nilai $\%$ Tp 9,30; 4,22 dan 2,80 semuanya termasuk dalam kategori total block.
\end{abstract}

Kata Kunci : daun kersen, losio tabir surya, SPF, Transmisi eritema, Transmisi pigmentasi 


\title{
DETERMINATION OF SPF VALUE OF EXTRACT AND LOSIO OF SOLAR TREATMENT OF KERSEN LEAF ETHANOL EXTRACT (Muntingia calabura L.) USING UV-VIS SPECTROPHOTOMETRY METHODE
}

\begin{abstract}
Excessive and prolonged sun exposure can cause erythema and sunburn, premature aging and skin cancer. Kersen leaves contain total flavonoids and phenolics which can be used as active ingredients for making sunscreen lotion. This study was to determine the SPF value, the value of erythema transmission (\% Te) and the value of pigmentation Transmission (\% Tp) from extracts and lotions of kersen ethanol extract using the UvVis spectrophotometric method. Absorbance increases at wavelengths of 290-400 nm at intervals of $5 \mathrm{~nm}$. The results showed SPF extract values with a composition of 500 ppm, 1000 ppm, and 2000 ppm combined - 12 were 12.15 (maximum ability); 17,29 (ultra protection); and 22.01 (ultra protection). \% Te value 0.54; 0.16 and 0.05 all include the total block category, \% value Tp 2.50; 1.30 and 0.49 (total blocks). Whereas for losio with a concentration of $0.5 \%, 1 \%$ and $2 \%$ respectively the SPF value produced is 3.61 (minimum protection); 8.18 (maximum protection) and 10.13 (maximum protection). \% Te value 4.29 (extra protection); 1.58 (extra protection) and 0.99 (maximum protection). \% value Tp 9.30; 4.22 and 2.80 are all included in the total block category.
\end{abstract}

Keywords : kersen leaves, sunscreen lotion, SPF, erythema transmission, pigmentation transmission

\section{PENDAHULUAN}

Sinar matahari merupakan anugerah alam yang memiliki manfaat dan peran yang sangat penting. Sinar matahari disatu pihak sangat diperlukan oleh makhluk hidup, namun dilain pihak sinar matahari juga dapat memberikan dampak buruk terhadap kesehatan, terutama kesehatan kulit. Paparan sinar matahari berlebih dalam waktu lama dapat merusak lapisan kulit (Syarif,2017).

Spektrum elektromagnetik daerah ultraviolet (UV), dibagi menjadi 3 daerah yaitu UV A 320-400 nm, UV B 290-320 nm dan UV C 200-290 nm.
Radiasi UV C disaring oleh atmosfer sebelum mencapai bumi. Radiasi UV B tidak sepenuhnya disaring oleh lapisan ozon yang dapat menyebabkan kulit terbakar matahari (sunburn), sedangkan radiasi UV A mampu mencapai lapisan epidermis dan dermis lebih dalam, serta dapat memicu penuaan dini pada kulit. Efek berbahaya dari radiasi UV pada kulit dapat dibagi menjadi 2 yaitu : efek akut seperti kulit terbakar atau eritema, reaksi fototoksik, fotoalergi dan fotosensitivitas serta efek kronis yaitu fotoaging, kanker kulit dan imunosupresi (Damayanti dkk., 2017). 
Untuk mencegah semua efek yang disebabkan oleh sinar matahari maka sangat penting menggunakan perlindungan secara kimiawi yaitu penggunaan tabir surya. Tabir surya adalah suatu sediaan yang mengandung senyawa kimia yang dapat menyerap, menghamburkan atau memantulkan sinar UV yang mengenai kulit sehingga dapat digunakan untuk melindungi fungsi dan struktur kulit manusia dari efek negatif sinar UV (Oktaviasari dkk., 2017). Tabir surya yang beredar dipasaran pada umumnya terbuat dari bahan sintetik. Bahan alam belum banyak dimanfaatkan dalam industri produk tabir surya. Salah satu tanaman yang berkhasiat sebagai tabir surya alami adalah daun kersen (Muntingia calabura L.). Daun kersen mengandung senyawa flavonoid, saponin, polifenol dan tannin sehingga dapat digunakan sebagai antioksidan (Mulangsari dan Puspitasari, 2018). Terdapat penelitian bahwa tumbuhan yang mengandung senyawa metabolit sekunder berupa flavonoid dan fenol berguna sebagai penangkap radikal bebas, yang memiliki aktivitas sebagai antioksidan. Kandungan senyawa metabolit sekunder pada ekstrak etanol daun kersen yaitu fenolik, flavanoid, dan saponin. Senyawa flavanoid berfungsi sebagai anti oksidan dimana telah dibuktikan dengan hasil dari penelitian Sutrisno dkk. (2017), ekstrak etanol daun kersen menghasilkan nilai $\mathrm{IC}_{50} 6,8249 \mathrm{ppm}$ dan kuersetin $\mathrm{IC}_{50} 4,2354$ ppm. Dari hasil tersebut dapat disimpulkan bahwa ekstrak etanol daun kersen memiliki aktivitas antioksidan sangat kuat karena nilai $\mathrm{IC}_{50}<50 \mathrm{ppm}$. Karena memiliki kandungan flavonoid dan fenolik inilah maka selain sebagai antioksidan daun kersen juga dapat dimanfaatkan sebagai tabir surya (Puspitasari dan Setyowati, 2018).

Penetapan potensi tabir surya yang baik dapat ditinjau dari kemampuannya dalam menyerap atau memantulkan sinar ultraviolet dengan penentuan nilai SPF serta persentase eritema dan pigmentasinya. SPF (Sun Protecting Factor) merupakan indikator universal yang menjelaskan tentang keefektifan dari suatu produk atau zat yang bersifat UV protektor, semakin tinggi nilai SPF dari suatu produk atau zat aktif tabir surya maka semakin efektif untuk melindungi kulit dari pengaruh buruk sinar UV. Untuk melihat potensi suatu produk tabir surya dalam menyerap sinar ultraviolet maka dapat ditentukan dengan menentukan nilai SPF dan mengukur persentase Transmisi eritema (\%Te) dan persentase Transmisi pigmentasi (\% Tp) sediaan tersebut. Sehingga suatu sediaan tabir surya dapat dikategorikan sebagai sunblock, proteksi ekstra, suntan, atau fast tanning (Yasin, 2017). Penelitian ini bertujuan untuk menentukan nilai SPF, persentase Transmisi eritema (\%Te) dan persentase Transmisi pigmentasi (\%Tp) ekstrak dan losio ekstrak etanol daun kersen secara in vitro menggunakan spektrofotometrer UV-Vis., kemudian potensi tabir surya dikategorikan berdasarkan tabel 1 dan tabel

2. 
Tabel 1. Keefektifan tabir surya berdasarkan nilai SPF

(Yasin, 2017)

\begin{tabular}{cc}
\hline SPF & Kategori Proteksi Tabir Surya \\
\hline $2-4$ & Proteksi minimal \\
$4-6$ & Proteksi sedang \\
$6-8$ & Proteksi ekstra \\
$8-15$ & Proteksi maksimal \\
$\geq 15$ & Proteksi ultra
\end{tabular}

Tabel 2. Penggolongan potensi tabir surya (Yasin, 2017)

\begin{tabular}{ccc}
\hline Kategori & \multicolumn{2}{c}{$\%$ Transmisi } \\
\cline { 2 - 3 } & Eritema & Pigmentasi \\
\hline Sunblock/ total block & $<1 \%$ & $3-40 \%$ \\
Proteksi ekstra & $1-6 \%$ & $42-86 \%$ \\
Suntan standar & $6-12 \%$ & $45-86 \%$ \\
Fast tanning & $10-18 \%$ & $45-86 \%$ \\
& & \\
\hline
\end{tabular}

\section{METODE PENELITIAN}

\section{MATERIAL}

Daun Kersen, etanol 70\%, etanol p.a, akuades, asam stearat, trietanolamin (TEA), gliserin, parafin cair, setil alkohol, metilparaben, dan sebagai kontrol positif digunakan titanium dioksida (TiO2).

\section{Rancangan Penelitian}

\section{1) Pembuatan Ekstrak Etanol Daun Kersen}

Proses pembuatan ekstrak dilakukan dengan metode maserasi menggunakan pelarut etanol $70 \%$. Daun kersen yang

Nilai rendemen
2) Pembuatan Losio Ekstrak larut minyak (asam stearat, setil Etanol Daun Kersen

Disiapkan alat dan bahan yang akan digunakan. Bahan-bahan yang alkohol, dan parafin cair) dimasukkan ke dalam cawan penguap. Bahan-bahan yang larut air (trietanolamin, gliserin sudah dikeringkan kemudian diblender menjadi bubuk halus. Bubuk daun kersen ditimbang dan direndam dalam bejana maserasi yang tidak tembus cahaya dengan alkohol $70 \%$ dengan perbandingan 1:10. Proses maserasi dilakukan selama 3 hari dengan pengadukan. Kemudian maserat disaring dengan menggunakan kertas saring dan filtrat diuapkan dalam penangas air untuk mendapatkan ekstrak etanol. Selanjutnya dihitung nilai rendemennya dengan menggunakan rumus: 
dan aquades) dimasukkan ke dalam gelas beker. Fase minyak dan fase air dipanaskan dan diaduk pada suhu 70$75^{\circ} \mathrm{C}$ secara terpisah hingga homogen kemudian dicampurkan pada suhu $70^{\circ} \mathrm{C}$, sambil diaduk hingga kedua fase homogen dan mencapai suhu $40^{\circ} \mathrm{C}$.
Pengawet (metil paraben), essence, dan zat aktif ekstrak etanol daun kersen dimasukkan kedalam campuran pada suhu $35^{\circ} \mathrm{C}$, kemudian dilakukan pengadukan selama kurang lebih satu menit (Mulyani dkk., 2018).

Tabel 3. Formula losio ekstrak etanol daun kersen

(Mulyani dkk., 2018)

\begin{tabular}{lccccc}
\hline \multirow{2}{*}{ NAMA BAHAN } & \multicolumn{5}{c}{ KONSENTRASI $(\% \mathrm{~b} / \mathrm{v})$} \\
\cline { 2 - 6 } & Fo $(-)$ & Fo $(+)$ & Fo 1 & Fo 2 & Fo 3 \\
\hline Ekstrak daun kersen & - & - & 0,5 & 1 & 2 \\
Titanium dioksida & - & 10 & - & - & - \\
Asam stearat & 2 & 2 & 2 & 2 & 2 \\
Trietanolamin & 4 & 4 & 4 & 4 & 4 \\
Parafin cair & 8 & 8 & 8 & 8 & 8 \\
Setil alkohol & 2 & 2 & 2 & 2 & 2 \\
Gliserin & 8 & 8 & 8 & 8 & 8 \\
Methyl paraben & 0,1 & 0,1 & 0,1 & 0,1 & 0,1 \\
Esesence & 3 tetes & 3 tetes & 3 tetes & 3 tetes & 3 tetes \\
Aquadest ad & 100 & 100 & 100 & 100 & 100 \\
\hline
\end{tabular}

Keterangan :

Fo (-) : Formula losio kontrol negatif (formula losio tanpa zat aktif)

Fo (+) : Formula losio kontrol positif (formula losio zat aktif titanium dioksida)

Fo 1 : Formula losio dengan konsentrasi ekstrak $0,5 \%$

Fo 2 : Formula losio dengan konsentrasi ekstrak $1 \%$

Fo 3 : Formula losio dengan konsentrasi ekstrak 2\%

3) Penentuan Nilai SPF, \% Te dan \% Tp Ekstrak Etanol Daun Kersen

Ditimbang ekstrak etanol daun kersen sebanyak 0,050 g, 0,100 g dan $0,200 \mathrm{~g}$. Kemudian diencerkan dengan etanol p.a hingga $10 \mathrm{ml}$ (500 ppm, 1000 ppm dan 2000 ppm). Larutan yang diperoleh disaring dan diendapkan menggunakan alat sentrifuge pada kecepatan $3000 \mathrm{rpm}$ selama 10 menit. Disiapkan larutan blanko yaitu etanol p.a. Diukur absorbansinya dengan spektrofotometer UV-Vis pada panjang gelombang 290-320 nm untuk penentuan nilai SPF ekstrak, pada panjang gelombang 292,5-317,5 nm untuk penentuan nilai \%Te ekstrak dan pada panjang gelombang 322,5-372,5 nm untuk penentuan nilai \% Tp ekstrak dengan interval panjang gelombang 5 nm. Pengujian dilakukan dengan replikasi tiga kali untuk masing-masing konsentrasi. 
4) Penentuan Nilai SPF, \% Te dan \% Tp Losio Ekstrak Etanol Daun Kersen

Ditimbang masing- masing 0,5 gram sampel losio $\mathrm{Fo}(-)$, Fo(+), Fo1, Fo2 dan Fo3 dilarutkan dalam $25 \mathrm{ml}$ (20.000 ppm). Larutan yang diperoleh disaring dan diendapkan menggunakan alat sentrifuge pada kecepatan $3000 \mathrm{rpm}$ selama 10 menit. Disiapkan larutan blanko yaitu etanol p.a. Larutan yang diperoleh diukur serapannya dengan spektrofotometer UV-Vis pada panjang gelombang 290-320 nm untuk penentuan nilai SPF losio, pada panjang gelombang 292,5-317,5 nm untuk penentuan nilai \%Te losio dan pada panjang gelombang 322,5-372,5 $\mathrm{nm}$ untuk penentuan nilai \% Tp losio dengan interval $5 \mathrm{~nm}$ tiap panjang gelombangnya. Sebelum pengukuran dilakukan kalibrasi terlebih dahulu spektrofotometer UV-Vis dengan menggunakan etanol p.a. Masing- masing pengujian dilakukan dengan 3 kali replikasi untuk masing-masing formula.

\section{5) Analisis Data}

Hasil absorbansi dari masingmasing panjang gelombang untuk ekstrak dan losio ekstrak etanol daun kersen didokumentasikan kemudian dihitung nilai SPF, \%Te dan \%Tp diolah dengan menggunakan rumus sebagai berikut:

Penentuan Nilai SPF

Penentuan nilai SPF dihitung menggunakan persamaan matematis sbb:

$\mathrm{SPF}=\mathrm{CF} \times \sum_{290}^{320} E E \lambda \times \mathrm{I} \times \mathrm{Abs}$

Keterangan :

EE $\quad=$ Spektrum efek eritema

I $=$ Spektrum intensitas

sinar

Abs $\quad=$ Absorbansi

$\mathrm{CF} \quad=$ Faktor koreksi $(=10)$

Nilai EE $x$ I adalah konstan dan ditunjukkan pada tabel 4

Tabel 4. Nilai EE $x$ I pada panjang gelombang 290-320 $\mathrm{nm}$

(Puspitasari dan Setyowati, 2018)

\begin{tabular}{cc}
\hline $\begin{array}{c}\text { Panjang gelombang } \\
(\mathrm{nm})\end{array}$ & EE x I \\
\hline 290 & 0,0150 \\
295 & 0,087 \\
300 & 0,2874 \\
305 & 0,3278 \\
310 & 0,1864 \\
315 & 0,0839 \\
320 & 0,0180 \\
\hline
\end{tabular}

Penentuan Nilai \%Te

Dari data pengamatan nilai transmitan pada berbagai panjang gelombang dapat dihitung persen Transmisi eritema dengan cara berikut :
1. Nilai Transmisi eritema adalah T Fe. Perhitungan nilai Transmisi eritema tiap panjang gelombang (panjang gelombang 292,5-317,5 nm). 
2. Banyaknya fluks eritema yang diteruskan oleh bahan tabir matahari (Ee) dihitung dengan rumus $\mathrm{Ee}=$ $\sum T . F e$

Kemudian \% Transmisi eritema dihitung dengan rumus :

$\%$ Transmisi eritema $=\frac{E e}{\sum F_{e}}$

Dimana :

$\mathrm{T}=$ Nilai transmisi

$\mathrm{Fe} \quad=$ Fluks eritema

$\mathrm{Ee} \quad=\sum T . F e$

$\sum T . F e=$ banyaknya fluks eritema yang diteruskan oleh ekstrak pada panjang gelombang 322,5 - $372,5 \mathrm{~nm}$

Penentuan Nilai \%Tp

Dari data pengamatan nilai transmitan pada berbagai panjang gelombang dapat dihitung persen Transmisi pigmentasi dengan cara berikut :

1. Nilai Transmisi pigmentasi adalah $\mathrm{T}$ Fp. Perhitungan nilai Transmisi pigmentasi tiap panjang gelombang (panjang gelombang 292,5 - 372,5 $\mathrm{nm})$.

2. Banyaknya fluks pigmentasi yang diteruskan oleh bahan tabir matahari (Ep) dihitung dengan rumus Ep = $\sum T . F p$

Kemudian \% Transmisi pigmentasi dihitung dengan rumus :

$\%$ Transmisi pigmentasi $=\frac{E p}{\Sigma F p}$

Dimana :

$\mathrm{T}=$ Nilai transmisi

$\mathrm{Fp} \quad=$ Fluks pigmentasi

Ep $\quad=\sum T . F p$

$\sum T \cdot F p=$ banyaknya fluks pigmentasi yang diteruskan oleh ekstrak pada panjang gelombang 292,5-372,5 nm

\section{HASIL DAN PEMBAHASAN \\ Pembuatan Ekstrak Etanol Daun Kersen}

Hasil rendemen yang didapatkan dari proses ekstraksi yaitu $26,91 \%$. Semakin tinggi nilai rendemen yang dihasilkan menandakan nilai ekstrak yang dihasilkan semakin banyak dan semakin tinggi zat berkhasiat yang dihasilkan (Wijaya dkk, 2018).

\section{Pembuatan Losio Ekstrak Etanol Daun Kersen}

Ekstrak etanol daun kersen yang didapat kemudian dibuat sediaan losio. Losio ekstrak etanol daun kersen dibuat dengan menggunakan kombinasi dua emulgator yaitu asam stearat dan trietanolamin. Selain emulgator, pada formulasi ini juga menggunakan setil alkohol untuk meningkatkan stabilitas dari emulsi, parafin cair sebagai emolient, gliserin sebagai humectan serta emolient. Emolient merupakan pelembut, dimana losio dengan penambahan zat emolient dapat membuat kulit terasa nyaman, kering, dan tidak berminyak (Kurniawan, 2012). Sedangkan humectan merupakan zat pembasah yang akan melindungi emulsi dari kekeringan dengan mempertahankan kandungan air produk saat pemakaian pada permukaan kulit. Selain itu juga menggunakan metil paraben yang berfungsi sebagai pengawet pada sediaan losio yang akan menambah kestabilan sediaan.Zat aktif dalam formula yang digunakan yaitu ekstrak daun kersen dengan variasi konsentrasi $0,5 \%$ untuk formula 1 (Fo1), 1\% untuk formula 2 (Fo2) dan $2 \%$ untuk formula 3 (Fo3). Selain itu 
juga dibuat formula losio kontrol negatif (Fo-) yang hanya berisi basis saja dan formula kontrol positif $(\mathrm{Fo}+)$ yang berisi basis losio dengan zat aktif titanium dioksida (10\%).

\section{Penentuan Nilai SPF, \% Te dan \% Ekstrak Etanol Daun Kersen}

Metode untuk penentuan nilai SPF ada 2 macam, yaitu dengan cara menentukan karakteristik tabir surya menggunakan analisis spektrofotometri dan mengukur serapan atau transmisi UV melalui lapisan produk tabir surya pada plat kuarsa atau biomembran (Yulianti dkk., 2015). Penentuan nilai SPF (Sun Protection Factor), nilai
Transmisi eritema (\%Te) dan nilai Transmisi pigmentasi (\%Tp) dilakukan secara in vitro dengan menggunakan metode spektrofotometri. Keuntungan menggunakan metode ini adalah lebih praktis, lebih murah dan bisa dilakukan dalam periode yang pendek (Mulyani dkk., 2015).

Penentuan nilai SPF Ekstrak

Nilai SPF didefinisikan sebagai perbandingan energi UV yang dibutuhkan untuk menghasilkan eritema minimal pada kulit yang dilindungi dengan eritema yang sama pada kulit yang tidak dilindungi dalam individu yang sama (Syarif, 2017).

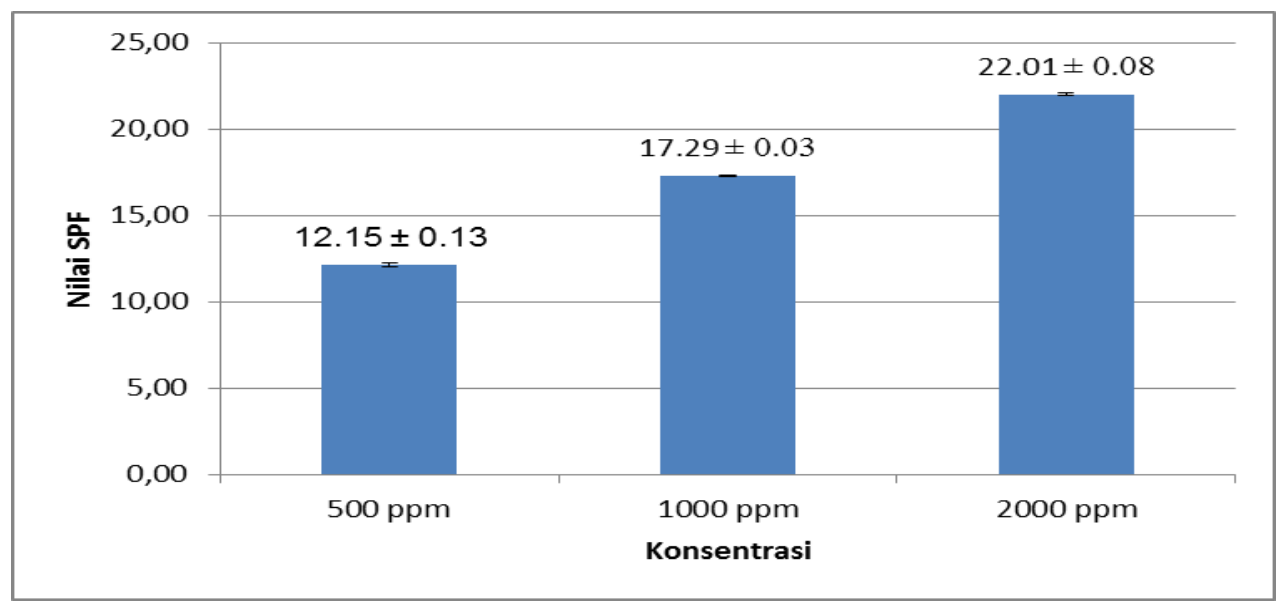

Gambar 1. Grafik Nilai SPF Ekstrak Etanol Daun Kersen

Berdasarkan data grafik (gambar 1), dari pengujian nilai SPF ekstrak etanol daun kersen diperoleh hasil dimana nilai rata-rata SPF konsentrasi 500 ppm, 1000 ppm dan 2000 ppm berturut- turut adalah 12,5; 17,29 dan 22,01. Hasil tersebut menunjukkan efektivitas tabir surya dari ekstrak dengan konsentrasi 500 ppm berproteksi maksimal dengan range 8-15 sedangkan ekstrak dengan konsentrasi 1000 dan 2000 ppm berproteksi ultra dengan range lebih dari 15 (Yasin, 2017), dan dapat dilihat bahwa semakin tinggi konsentrasi maka semakin tinggi nilai SPFnya. Semakin tinggi nilai SPF, semakin efektif aktivitas tabir suryanya (Saadah dkk., 2016). Berdasarkan hal tersebut ekstrak etanol daun kersen terbukti mempunyai nilai SPF yang tinggi.

\section{Penentuan Nilai \% Te Ekstrak \\ Persen Transmisi eritema adalah perbandingann jumlah energi sinar UV}


yang diteruskan oleh sediaan tabir surya pada spektrum eritema dengan jumlah faktor keefektifan eritema pada tiap panjang gelombang dalam rentang 292,5 nm-317,5 nm (Yasin, 2017).

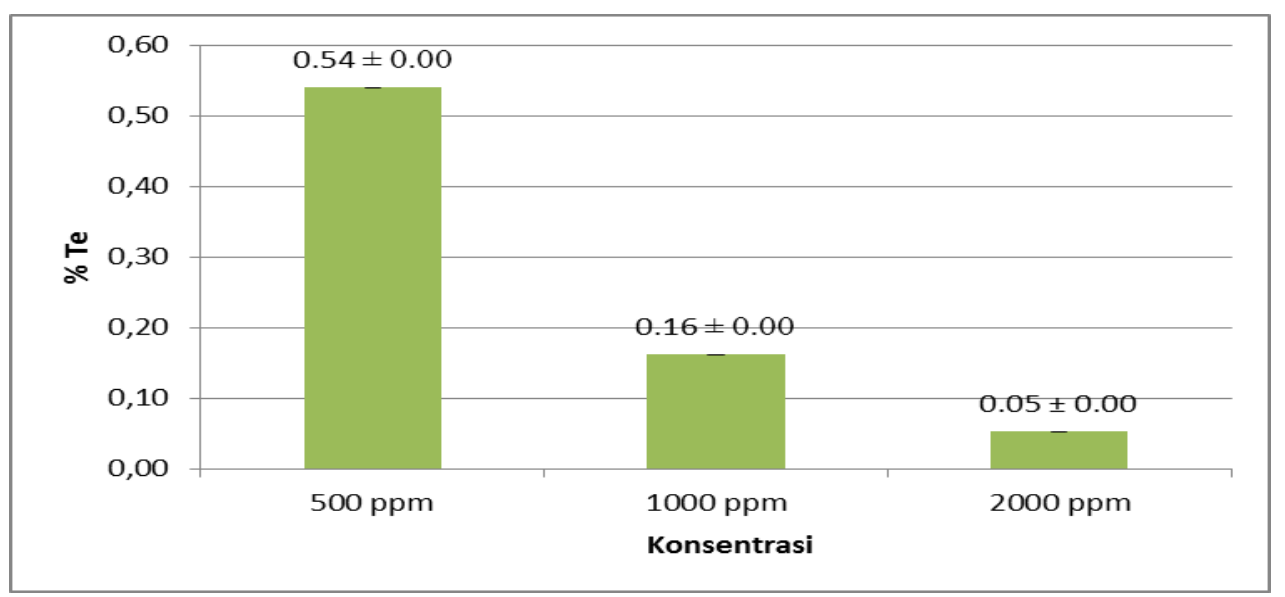

Gambar 1. Grafik Nilai \% Te Ekstrak Etanol Daun Kersen

Berdasarkan data grafik (gambar 2), didapatkan nilai rata-rata \%Te ekstrak etanol daun kersen dengan konsentrasi $500 \mathrm{ppm}, 1000 \mathrm{ppm}$ dan $2000 \mathrm{ppm}$ berturut-turut adalah 0,$54 ; 0,16$; dan 0,05 . Efektivias tabir surya dari 3 konsentrasi ekstrak yang diujikan semuanya memiliki potensi total block atau sunblock karena nilai yang diperoleh ketiga konsentrasi ekstrak dengan range kurang dari $1 \%$, dimana dapat diartikan jika ekstrak etanol daun kersen dapat menyerap hampir semua sinar UVB dan UVA (Yasin, 2017).

Penentuan nilai \% TP Ekstrak

Persentase Transmisi pigmentasi adalah perbandingan jumlah energi sinar UV yang diteruskan oleh sediaan tabir surya pada spectrum pigmentasi dengan jumlah faktor keefektifan eritema pada tiap panjang gelombang dalam rentang $322,5 \mathrm{~nm}-372,5 \mathrm{~nm}$.

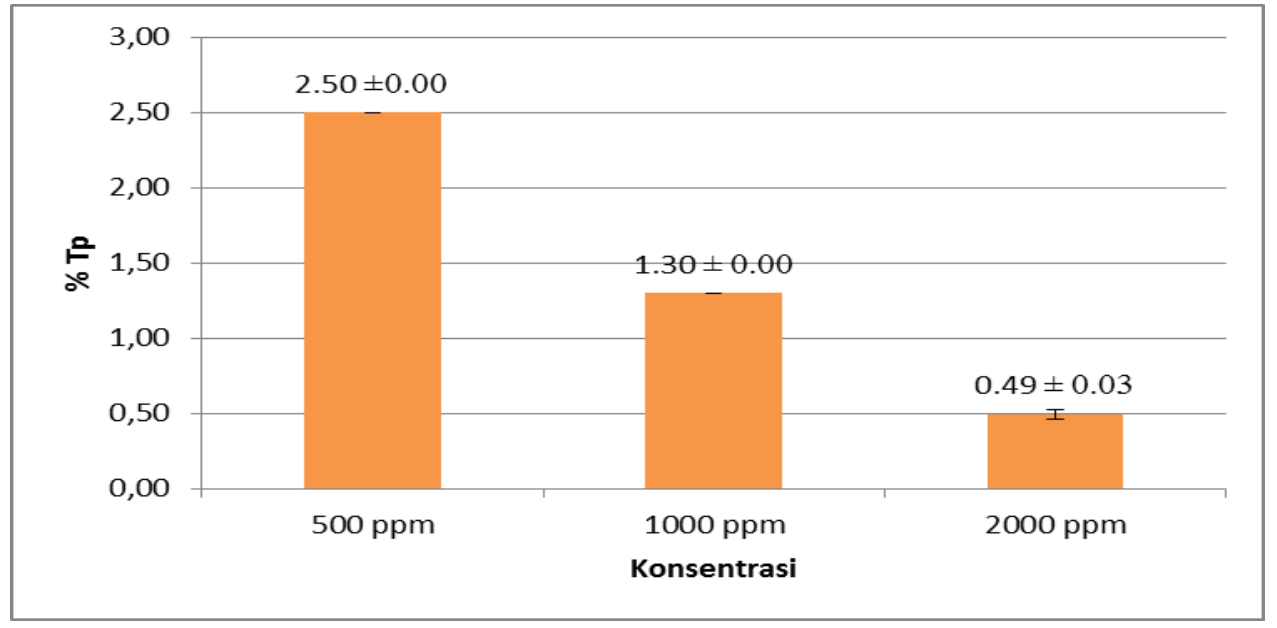

Gambar 2. Grafik Nilai \% Tp Ekstrak Etanol Daun Kersen 
Berdasarkan grafik (gambar 3), dapat diketahui nilai rata-rata Transmisi pigmentasi (\% Tp) da ekstrak etanol daun kersen dengan konsentrasi 500 ppm, 1000 ppm dan 2000 ppm berturutturut adalah 2,50, 1,30 dan 0,49 . Dari nilai tersebut berarti semua konsentrasi ekstrak etanol daun kersen yang diuji mempunyai efektivitas tabir surya sebagai sunblock atau total block karena nilai \%Tp yang diperoleh dari ketiga konsentrasi ekstrak dengan range 3-40\% yang artinya adalah ekstrak etanol daun kersen dapat menyerap hampir semua sinar UV A dan UV B (Yasin, 2017).

Penentuan Nilai SPF, \% Te dan \% Tp Losio Ekstrak Etanol Daun Kersen

Penentuan potensi tabir surya ini dilakukan dengan menghitung nilai SPF (Sun Protection Factor), nilai Transmisi eritema (\%Te) energi UV yang dibutuhkan menunjukkan efektivitas tabir surya terhadap sinar UV B, dan nilai Transmisi pigmentasi (\%Tp) untuk melihat efektivitas tabir surya terhadap sinar UV A. Salah satu faktor yang mempengaruhi penentuan nilai SPF adalah kombinasi dan konsentrasi dari tabir surya, dimana faktor ini dapat menambah atau mengurangi penyerapan UV pada setiap tabir surya. Berdasarkan hal tersebut, menunjukkan bahwa semakin tinggi konsentrasi, maka daya proteksi terhadap sinar UV juga semakin tinggi. Suatu sediaan tabir surya dikatakan memiliki efektivitas yang baik apabila memiliki nilai SPF yang tinngi, serta memiliki nilai persen transmisi eritema dan pigmentasi yang rendah (Syarif, 2017). Pada pengujian nilai SPF, \%Te dan \%Tp dari losio terdapat 2 formula kontrol yaitu formula kontrol negatif (Fo-) hanya berisi basis saja, tujuannya untuk melihat pengaruh basis terhadap nilai SPF, \%TE dan \%TP. Sedangkan formula kontrol positif (Fo+) yang berisi basis dan titanium dioksida. Titanium dioksida tergolong ke dalam jenis tabir surya fisik. Tabir surya fisik mempunyai mekanisme kerja dengan cara memantulkan dan menghamburkan radiasi sinar ultraviolet dan tidak tembus cahaya.

Penentuan Nilai SPF Losio

SPF (Sun Protection Factor) merupakan indikator universal yang menjelaskan tentang keefektifan dari suatu produk atau zat yang bersifat $U V$ protector, semakin tinggi nilai SPF dari suatu produk atau zat aktif tabir surya, maka semakin efektif untuk melindungi kulit dari pengaruh sinar UV (Haeria dkk.,2014). 


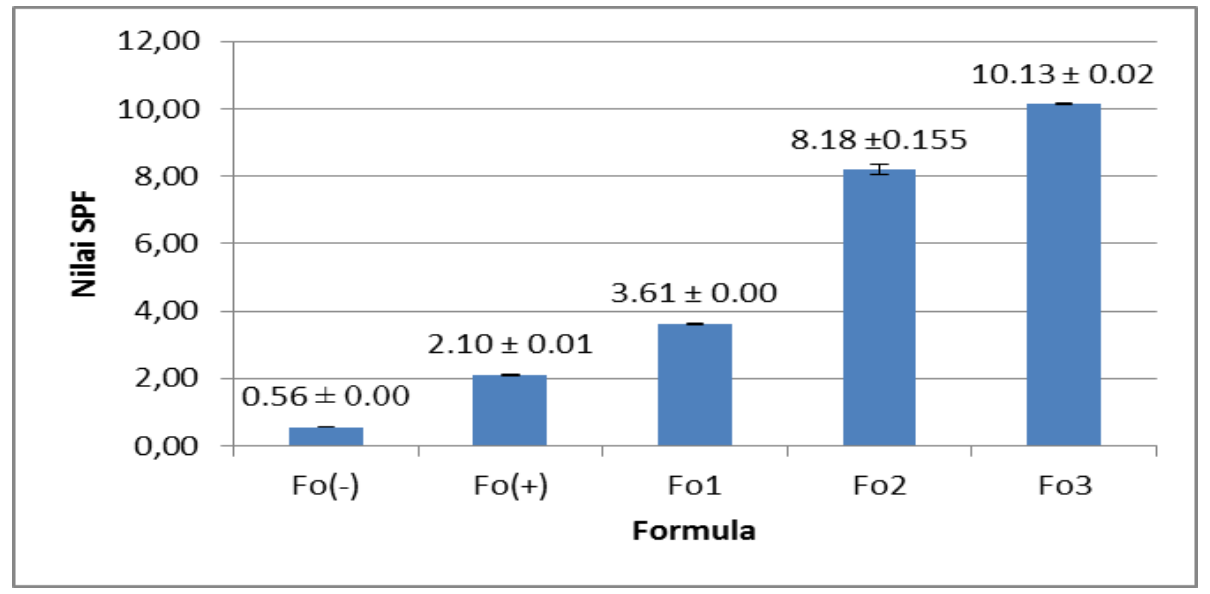

Gambar 4. Grafik Hasil Nilai SPF Losio

Dilihat dari grafik (gambar 4) dapat diketahui nilai rata-rata SPF dari 5 formula losio yang diuji. Adapun nilai rata-rata SPF yang didapatkan dari formula kontrol negatif, formula kontrol positif, formula 1 , formula 2 dan formula 3 berturut-turut adalah 0,56; 2,$10 ; 3,61 ; 8,18$ dan 10,13. Dari hasil nilai SPF yang didapatkan dapat diketahui jika semakin tinggi konsentrasi dari kandungan ekstrak semakin tinggi nilai SPFnya. Efektivitas tabir surya untuk formula ekstrak $0,5 \%$ masuk dalam kategori proteksi minimal Sedangkan untuk formula ekstrak $1 \%$ dan 2\% kategori proteksi maksimal. Formula kontrol positif masuk dalam kategori proteksi minimal karena hanya memiliki nilai SPF 2,10. Hal ini menunjukkan bahwa senyawa fenolik total dan flavonoid yang terkandung dalam daun kersen lebih berpotensi sebagai tabir surya.Pada formula kontrol negatif menghasilkan nilai absorbansi dan memiliki nilai SPF sebesar 0,56. Hal ini kemungkinan ada eksipien dalam losio yang menghasilkan pita absorbansi sehingga memiliki nilai SPF meskipun kecil.

Penentuan Nilai \% Te Losio

Persen Transmisi eritema (\% Te) menggambarkan jumlah sinar matahari yang diteruskan setelah mengenai tabir surya, sehingga dapat menyebabkan eritema kulit (kulit menjadi kemerahan).

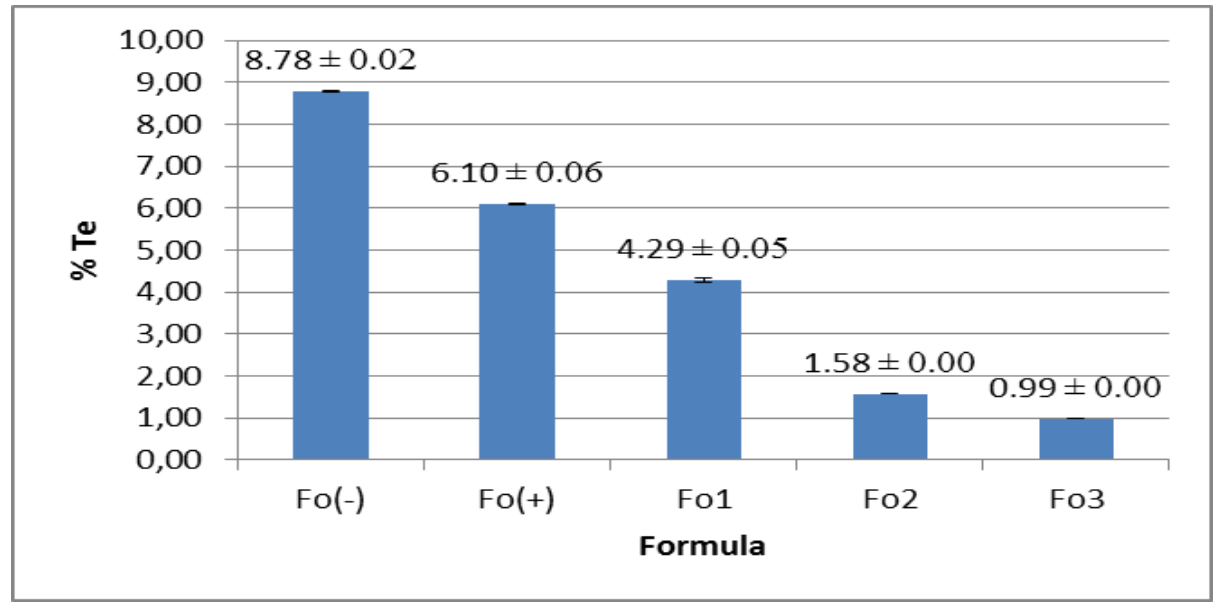




\section{Gambar 5. Grafik Hasil Nilai \% Te losio}

Grafik (gambar 5) menunjukkan hasil dari transmisi eritema (\%Te) dari 5 formula losio yang diuji. Hasil nilai rata-rata \% Te dari formula kontrol negatif, formula kontrol positif, formula 1, formula 2 dan formula 3 berturutturut adalah $8,78 \%$; $6,10 \%$; $4,29 \%, 1,58 \%$ dan 0,99\%. Dari hasil tersebut dapat dilihat bahwa semakin tinggi konsentrasi semakin kecil nilai persentase Transmisi eritemanya. Yang berarti semakin kecil suatu \% Te suatu sediaan berarti semakin sedikit sinar UV yang diteruskan sehingga dapat dikatakan bahwa sediaan tersebut memiliki aktifitas yang besar sebagai tabir surya (Yasin, 2017). Pada formula 3 yaitu formula dengan konsentrasi ekstrak 2\% termasuk golongan potensi tabir surya total block atau sunblock. Formula 1 (ekstrak 0,5\%) dan formula 2 (ekstrak 1\%) termasuk golongan tabir surya extra protection etanol daun kersen lebih berpotensi sebagai tabir surya dibandingkan dengan formula kontrol positif (titanium dioksida 10\%) yang dari hasil uji termasuk golongan potensi tabir surya regular suntan, yang dapat dikatakan suatu bahan yang menyerap sebagian besar sinar UV B dan menyerap sedikit sinar UV A.

Penentuan Nilai Tp Losio

Persen Transmisi Pigmentasi (\%Tp) menggambarkan jumlah sinar matahari yang dapat menyebabkan pigmentasi kulit (kulit menjadi gelap).

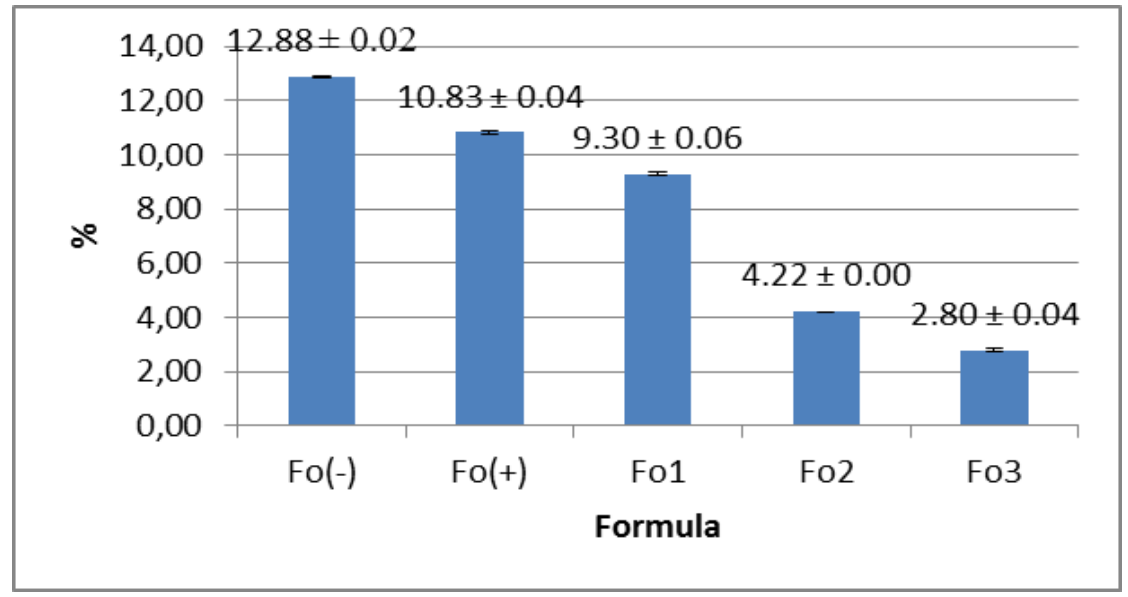

Gambar 6. Grafik Hasil Nilai \% Tp Losio

Grafik (gambar 6) menunjukkan hasil nilai rata-rata nilai persentase Transmisi pigmentasi (\% $\%$ p) dari 5 formula losio yang diuji. Nilai \%Tp dari formula kontrol negatif, formula kontrol positif, formula 1, formula 2 dan formula 3 secara berturut-turut adalah 12,88; 10,$83 ; 9,30 ; 4,22$ dan 2,80 \%. Dari data tersebut dapat dinyatakan semakin tinggi konsentrasi dari losio semakin kecil nilai \%Tp yang didapatkan. Ke 3 formula yang mengandung ekstrak etanol daun kersen memiliki efektivitas tabir surya total block atau sunblock. Kesimpulan yang bisa diambil dari hasil uji penentuan nilai SPF, \%Te dan \%Tp losio tabir surya formula 3 (konsentrasi ekstrak etanol daun kersen 2\%) berproteksi ultra dan berpotensi total block. Hal tersebut membuktikan bahwa 
senyawa metabolit yang terkandung didalam daun kersen antara lain flavonoid, fenolik dan tannin dapat berperan sebagai tabir surya.

\section{SIMPULAN}

1. Ekstrak daun kersen dapat dijadikan sebagai zat aktif dalam pembuatan sediaan losio tabir surya.

2. Hasil efektifitas tabir surya ekstrak etanol daun kersen yang memiliki aktifitas terbesar yaitu pada konsentrasi 2000 ppm dengan nilai SPF 22,01 (proteksi ultra), \%, Te 0,05 (total block), dan \% Tp 0,49 (total block).

3. Hasil efektifitas tabir surya losio ekstrak etanol daun kersen yang memiliki aktifitas terbesar yaitu pada formula 3 dengan nilai SPF 10,3 (proteksi maksimal), \%, Te 0,99 (total block), dan \% Tp 2,80 (total block).

\section{UCAPAN TERIMA KASIH}

Pada kesempatan ini, peneliti ingin mengucapkan terima kasih kepada berbagai pihak yang telah membantu terwujudnya penelitian ini :

1. Direktur Akademi Farmasi Nusaputera Semarang

2. Seluruh Dosen dan Staf Akademi Farmasi Nusaputera Semarang

\section{DAFTAR PUSTAKA}

Damayanti. R.H, Meylina. L, dan Rusli. R, 2017, Formulasi Sediaan LotionAntioksidant Lotion Tabir Surya Ekstrak Daun Cempedak (Artocarpus champeden Spreng)., 1, 167172.

Haeria, Ningsi. S, dan Israyani, 2014, Penentuan Potensi Tabir Surya Ekstrak Klika Anak Dara (Croton Oblongus Burm.F)., 2, 1-5.

Indraswari. A, 2008, Optimasi Pembuatan Ekstrak Daun Dewandaru (Eugenia ulnifloria L.) Menggunakan Metode Maserasi Dengan Parameter Kadar Total Senyawa Fenolik Dan Flavonoid, Skripsi, Fakultas Farmasi, Universitas Muhammadiyah, Surakarta.

Kurniawan. R, 2012, Pembuatan Body Lotion dengan Menggunakan Ekstrak Daun Handeuleum (Graptophyllum pictum L. Griff) Sebagai Emolient, Skripsi, Fakultas Teknik, Universitas Indonesia, Jakarta.

Mulangsri. D.A.K, dan Puspitasari. A.D, 2018, Uji Aktivitas Tabir Surya Ekstrak Etanol Daun Kersen (Muntingia calabura)., 2, 65-69.

Oktaviasari. L, dan Zulkarnain. A.K, 2016, Formulasi dan Stabilitas Fisik Sediaan Lotion O/W Pati Kentang (Solanum tuberosum L.) serta Aktivitasnya Sebagai Tabir Surya. Diss. Universitas Gadjah Mada., 13, 9-27.

Puspitasari. A.D, Setyowati. D.A, 2018, Evaluasi Karakteristik Fisika Kimia dan Nilai SPF Sediaan Gel Tabir Surya Ekstrak Etanol Daun Kersen 
(Muntingia calabura L.)., 5, 153-162.

Saadah. N, Ode. L.Z, dan Ervianingsih, 2016, Formulasi Lotion Tabir Surya Ekstrak Etanol Beras Merah. Kendari, Jurnal Ilmiah Ibnu Sina., 1, 143-150.

Sutrisno. B, Ramli. N, Nur. S, dan Sami. F.J, 2017, Uji Aktivitas Antioksidan Daun Kersen Dengan Metode DPPH (1,1difenil-2-pikrilhidrazil) dan FRAP (Ferric Reducing Antioxidan Power)., 9, 106-111

Syarif. ST, Umrah, 2017, Uji Potensi tabir Surya Ekstrak Daun Jambu Biji (Psidium guajava L.) Berdaging Putih secara In Vitro, Skripsi, Fakultas Farmasi, Universitas Islam Negeri Alauddin, Makasar.
Wijaya. H., Novitasari, dan Jubaidah. S, 2018, Perbandingan Metode Ekstraksi Terhadap Rendemen Ekstrak Daun Rambai Laut (Sonneratia Caseolaris $L$. Engl)., 4, 79-83.

Yasin. R.A, 2017, Uji Potensi tabir Surya Ekstrak Kulit Jeruk Nipis (Citrus aurantifolia) secara In Vitro. Skripsi, Fakultas Farmasi, Universitas Islam Negeri Alauddin, Makasar.

Yulianti. E, Adelsa. A, dan Putri. A, 2015, Penentuan nilai SPF (Sun Protection Factor) Ekstrak Etanol 70\% Temu Mangga (Curcuma manga) secara In Vitro Menggunakan Metode Spektrofotometri., 2, 1 